\title{
Squamata, Phyllodactylidae, Phyllodactylus thompsoni Venegas, Townsend, Koch and Böhme, 2008 and Phyllodactylus delsolari Venegas, Townsend, Koch and Böhme, 2008: Latitudinal and altitudinal distribution extension and geographic distribution map
}

\author{
Claudia Koch ${ }^{1 *}$ and Alfredo M. Beraún ${ }^{2}$ \\ 1 Forschungsmuseum Alexander Koenig (ZFMK), Department of Herpetology. Adenauerallee 160, D-53113 Bonn, Germany. \\ 2 Centro de Ornitología y Biodiversidad (CORBIDI). Santa Rita 117, Huertos de San Antonio. Surco, Lima, Perú. \\ * Corresponding author. E-mail: c.koch.zfmk@uni-bonn.de
}

\begin{abstract}
This work reports on the collection of the gekkonid species Phyllodactylus thompsoni and Phyllodactylus delsolari from seven and four new localities, respectively, extending the distribution of both species southward along the Río Marañón valley in Peru by about 130 km and the altitudinal range to nearly 1,900 m above sea level.
\end{abstract}

In 2008, two new species of the genus Phyllodactylus were described based on material collected in the southern area of the Región de Amazonas, Peru (Venegas et al. 2008). Phyllodactylus thompsoni (Figure 1) is a small species reaching only up to $42 \mathrm{~mm}$ snout-vent-length (SVL) and is the only representative of the genus with an enlarged postanal scale. In contrast, the other species identified, Phyllodactylus delsolari (Figure 2), is one of the largest representatives of the genus among those found in mainland South America, reaching up to $81 \mathrm{~mm} \mathrm{SVL}$ (Dixon and Huey 1970; Venegas et al. 2008). Previously, both species were known only from the type locality in the vicinity of the Balsas Village, at the base of the western slope of the Cordillera Central, between 900 and 1,400 m elevation (Venegas et al. 2008). Both species were found at night, either perched on vertical rock walls up to $5 \mathrm{~m}$ above the ground or actively moving on the ground nearby rocks. The mean air temperature during these nights was reported to be $27.3{ }^{\circ} \mathrm{C}$; the mean substrate temperature of the rocks was reported to be $28.8{ }^{\circ} \mathrm{C}$ (Venegas et al. 2008). The two species were found sympatric with the giant gecko Phyllopezus maranjonensis and the congener Phyllodactylus reissii (Koch et al. 2006; Venegas et al. 2008).

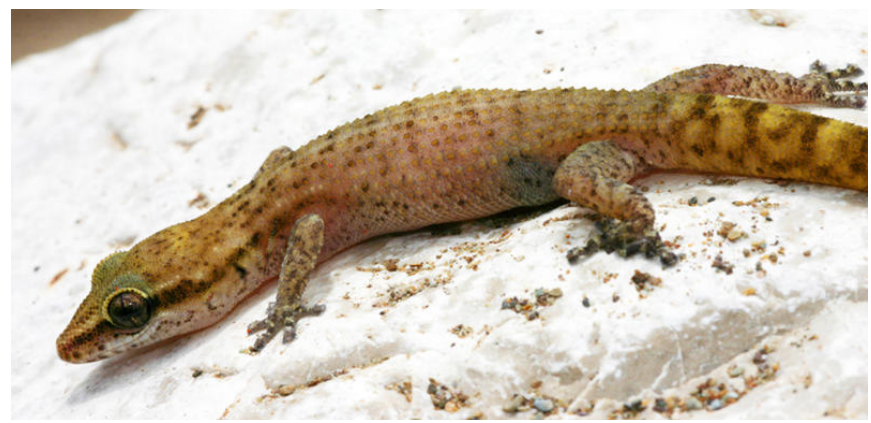

FIGURE 1. Phyllodactylus thompsoni from Laguna de Pias, La Libertad, Peru. Photo taken on 18 January 2010.
Here we provide seven new localities for $P$. thompsoni and four new localities for P. delsolari (Figure 3), based on our collected specimens, which were deposited in the collections of the Centro de Ornitología y Biodiversidad, in Lima, Peru (CORBIDI) and the Forschungsmuseum Alexander Koenig, in Bonn, Germany (ZFMK). Of the new localities, Laguna de Pias (Figure 4) represents the southernmost and also highest locality of both species and extends their distributional ranges southward along the Río Marañón valley by about $130 \mathrm{~km}$ and their altitudinal ranges to nearly $1,900 \mathrm{~m}$ above sea level.

Six specimens of $P$. thompsoni (CORBIDI 5717-5720, ZFMK 90912, 90913) were collected near the road between Chacanto and Limón, Provincia de Celendín, Región de Cajamarca (0650’ S, 7802' W; 1,135 m elevation), on 17 April 2009, by C. Koch and A. García, six specimens (CORBIDI 5722, 5723, ZFMK 90917, 90918, 90921, 90922) in San Vicente/Pusac, Provincia de Bolívar, Región de La Libertad (0659' S, 7755’ W; 1,430-1,670 m elevation), between 22-24 April 2009, by C. Koch and A. García, six specimens (CORBIDI 6903-6905, ZFMK 91740-91742 ) in Chagual, Provincia de Pataz, Región de La Libertad (0750' S, 77³8' W; 1,290-1,370 m elevation), between 6-8 January 2010, by C. Koch, E. Hoyos and A. M. Beraún, further six specimens (CORBIDI 6906-6908, ZFMK 91743-91745) in Vijus, Provincia de Pataz, Región

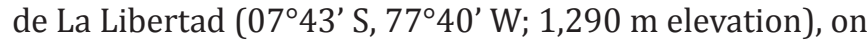
10 January 2010, by C. Koch, E. Hoyos and A. M. Beraún, six specimens (CORBIDI 6909-6911, ZFMK 91746-91748) in the surroundings of Laguna de Pias, Provincia de Pataz, Región de La Libertad (0754' S, 77³4' W; 1,850-1,880 m elevation), between 15-17 January 2010, by C. Koch, E. Hoyos and A. M. Beraún, seven specimens (CORBIDI 76817684, ZFMK 91749-91751) in Santa Rosa (Marcamachay), Provincia de Cajabamba, Región de Cajamarca $\left(07^{\circ} 22^{\prime}\right.$ S, 7753' W; 1,090-1,300 m elevation), between 12- 


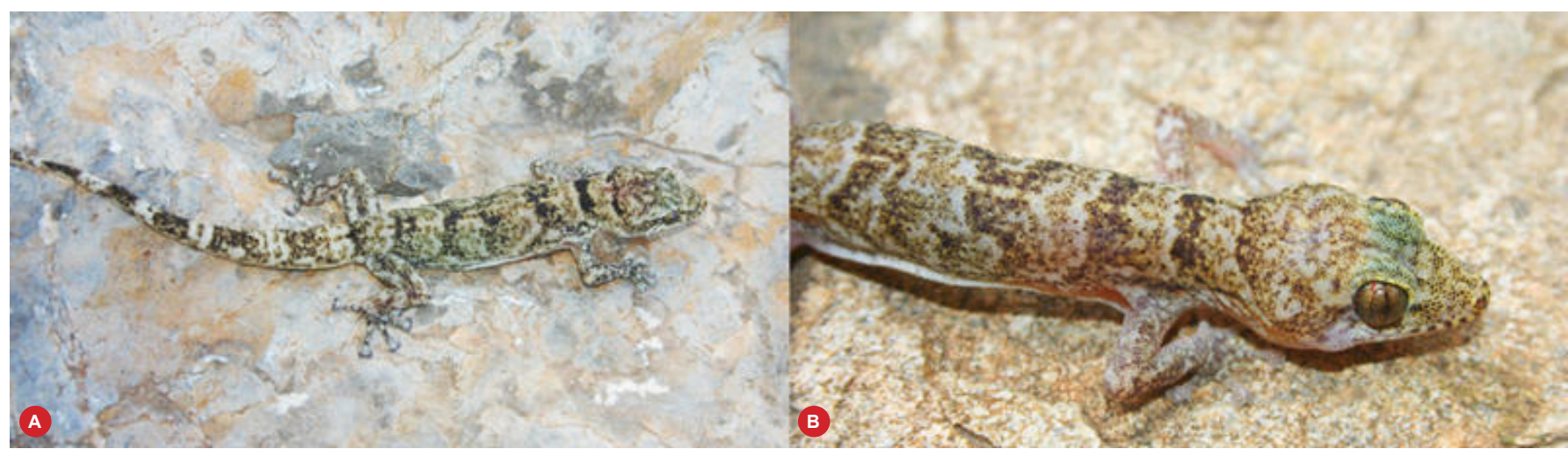

Figure 2. Phyllodactylus delsolari from Laguna de Pias, La Libertad, Peru. Photos taken on 18 January 2010; (a) total view and (b) close-up of the head and dorsum.

14 October 2010, by C. Koch and M. Palacios and six specimens (CORBIDI 7685-7687, ZFMK 91752-91754) in Calemar, Provincia de Bambamarca, Región de La Libertad (07³2' S, 77²2' W; 1,440-1,690 m elevation), between 19 October 2010, by C. Koch and M. Palacios (Table 1).

Three specimens of $P$. delsolari (CORBIDI 5672, 5673, ZFMK 90871) were collected in Chacanto, Provincia de Celendín, Región de Cajamarca (0650' S, 7801' W; 890 m elevation), on 16 April 2009, by C. Koch and A. García, four specimens (CORBIDI 6912, 6913, 7656, ZFMK 91761) in Vijus, Provincia de Pataz, Región de La Libertad (07²4' S, 77³9' W; 1,260-1,315 m elevation), between 13-14 January 2010, by C. Koch, E. Hoyos and A. M. Beraún, five specimens (CORBIDI 6914-6916, ZFMK 91759, 91760) in the surroundings of Laguna de Pias, Provincia de Pataz, Región de La Libertad (0753' S, 77³3' W; 1,820-1,870 m elevation), between 16-18 January 2010, by C. Koch, E. Hoyos and A. M. Beraún and six specimens (CORBIDI 7654, 7655, ZFMK 91755-91758) in Calemar Provincia de Bambamarca, Región de La Libertad (07³0' S, 77²4' W; 1,230-1,400 m elevation), between 19-20 October 2010, by C. Koch and M. Palacios (Table 2).

The specimens of $P$. thompsoni reported here have a maximum SVL of $43 \mathrm{~mm}$, between 10 and 12 rows of large and trihedral dorsal tubercles, enlarged trihedral tubercles on the dorsal surface of tibia, and an enlarged postanal scale, all characteristic of this species (Venegas et al. 2008). The specimens of $P$. delsolari reported here have a maximum SVL of $77 \mathrm{~mm}$, fewer than 10 poorly defined rows of small, smooth, round tubercles, and broad, welldefined dark dorsal cross-bands as described by Venegas et al. (2008).

The new records reported here are the first reports of the two species outside their type localities and the first registries of these species from the Regiones de Cajamarca and La Libertad. The initial conjecture by Venegas et al. (2008) that the species were endemic to the Balsas region is not supported by these findings. During our investigations we found the two species ( $P$. thompsoni, $P$. delsolari) sympatric in Vijus and La Laguna de Pias. In Calemar they both occurred sympatric with a third gekkonid species Phyllopezus maranjonensis. In addition, Phyllodactylus delsolari was found sympatric with Phyllopezus maranjonensis in Chacanto. Phyllodactylus thompsoni occurred sympatric with Phyllopezus maranjonensis in Santa Rosa (Marcamachay) and with Phyllodactylus reissii in San Vicente/Pusac. The latter was found to be a very abundant species in Marañón regions situated more than $100 \mathrm{~km}$ (linear distance) north of Balsas. In Balsas, as well as in San Vicente/Pusac, which are 20 linear kilometers apart, $P$. reissii could only be found in very low individual numbers. It seems as if the distribution of $P$. reissii and the two other species of Phyllodactylus overlap only in the Balsas and San Vicente/Pusac regions. From there, $P$. reissii is distributed northwards whereas $P$. thompsoni and P. delsolari are distributed southwards.

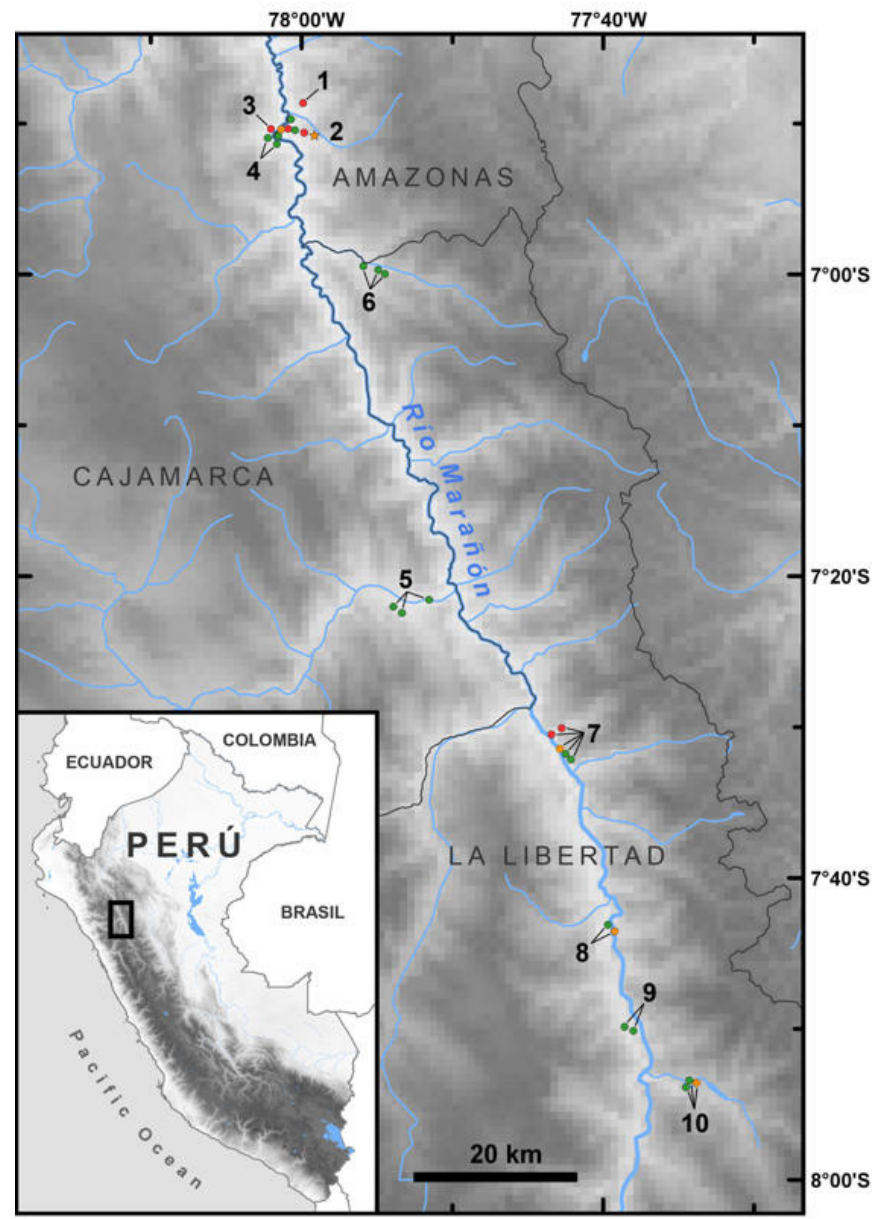

FIGURE 3. Map of Peru showing the new distributional ranges of $P$ delsolari (red dots) and P. thompsoni (green dots) based on the data presented here. The gold star marks the type locality of both species and the gold dots mark sympatric occurrences of both species. Localities: Amazonas Region: (1) Quebrada Honda/Llusca (Balsas), (2) Balsas; Cajamarca Region: (3) Chacanto, (4) Road between Chacanto and Limón, (5) Santa Rosa (Marcamachay); La Libertad Region: (6) San Vicente/ Pusac, (7) Calemar, (8) Vijus, (9) Chagual, (10) Laguna de Pias. 
All specimens of $P$. thompsoni and all but two specimens of $P$. delsolari were captured at night. The latter (ZFMK 91759, CORBIDI 6915) were detected during the day (11:20 am and 11:40 am) hidden in bore holes of a large boulder (Figure 5). While P. delsolari was exclusively found on rocks up to several meters above the ground, $P$. thompsoni was observed mainly on stones in areas of low vegetation or under/between fallen and decomposing cactus plants (Figure 6).

It becomes apparent that the species mentioned herein are still poorly documented. Further research is necessary to become more acquainted with their ecology and true distributional limits. Moreover, efforts should be made to characterize the conservation status of the species and to determine if they are threatened by the human influence on their habitats.

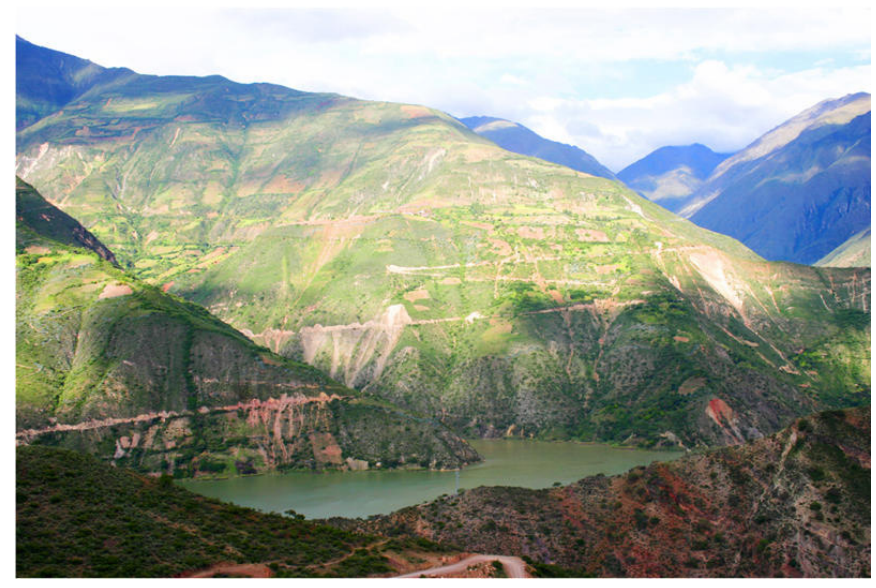

FIGURE 4. The southernmost locality where $P$. thompsoni and $P$. delsolari were found: Laguna de Pias, La Libertad, Peru, 1800 - 1900 m a.s.l.

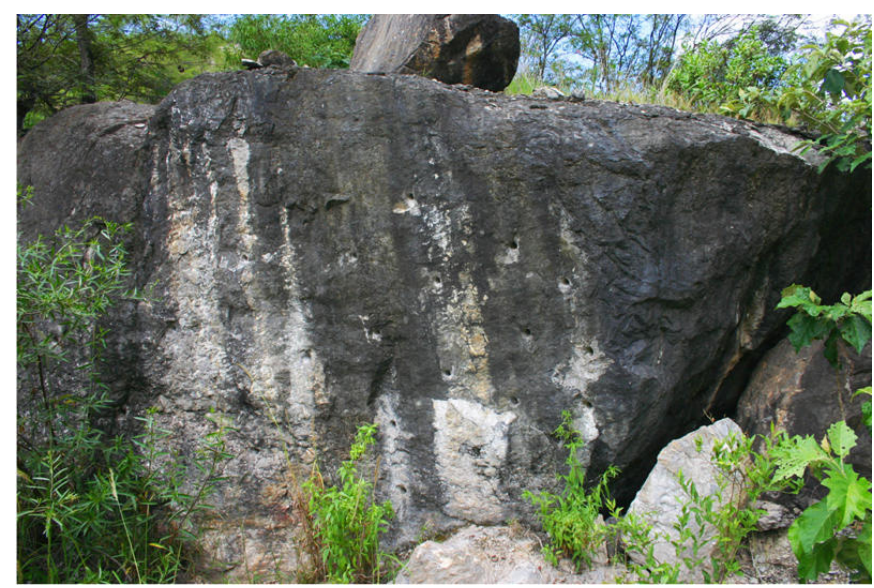

FIGURE 5. Microhabitat of $P$. delsolari at Laguna de Pias, La Libertad, Peru; two specimens where found during the day hidden in bore holes of this boulder.

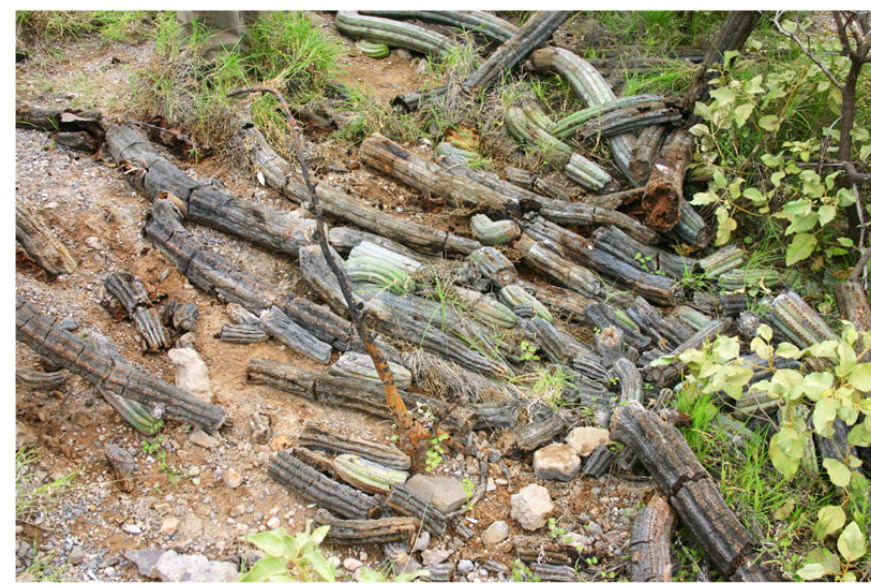

FigurE 6. Microhabitat of $P$. thompsoni near Chacanto, Cajamarca, Peru; almost half of the collected and sighted specimens where found under/ between such fallen and decomposing cactus plants.

TABLE 1. Seven new localities of P. thompsoni.

\begin{tabular}{|c|c|c|c|c|}
\hline REGIÓN & PROVINCIA & LOCALITY / COORDINATES & ALTITUDE & COLLECTION NUMBERS \\
\hline \multirow{2}{*}{ Cajamarca } & Celendín & $\begin{array}{l}\text { Road between Chacanto and Limón } \\
\left(06^{\circ} 50^{\prime} \mathrm{S}, 78^{\circ} 02^{\prime} \mathrm{W}\right)\end{array}$ & $1,135 \mathrm{~m}$ & CORBIDI 5717-5720, ZFMK 90912, 90913 \\
\hline & Cajabamba & $\begin{array}{l}\text { Santa Rosa (Marcamachay) } \\
\left(07^{\circ} 22^{\prime} \mathrm{S}, 77^{\circ} 53^{\prime} \mathrm{W}\right)\end{array}$ & $1,090-1,300 \mathrm{~m}$ & CORBIDI 7681-7684, ZFMK 91749-91751 \\
\hline \multirow{5}{*}{ La Libertad } & Bolívar & $\begin{array}{l}\text { San Vicente/Pusac } \\
\left(06^{\circ} 59^{\prime} \mathrm{S}, 77^{\circ} 55^{\prime} \mathrm{W}\right)\end{array}$ & $1,430-1,670 \mathrm{~m}$ & $\begin{array}{l}\text { CORBIDI 5722, 5723, ZFMK 90917, 90918, 90921, } \\
90922\end{array}$ \\
\hline & \multirow{3}{*}{ Pataz } & $\begin{array}{l}\text { Chagual } \\
\left(07^{\circ} 50^{\prime} \mathrm{S}, 77^{\circ} 38^{\prime} \mathrm{W}\right)\end{array}$ & $1,290-1,370 \mathrm{~m}$ & CORBIDI 6903-6905, ZFMK 91740-91742 \\
\hline & & $\begin{array}{l}\text { Vijus } \\
\left(07^{\circ} 43^{\prime} \mathrm{S}, 77^{\circ} 40^{\prime} \mathrm{W}\right)\end{array}$ & $1,290 \mathrm{~m}$ & CORBIDI 6906-6908, ZFMK 91743-91745 \\
\hline & & $\begin{array}{l}\text { Laguna de Pias } \\
\left(07^{\circ} 54^{\prime} \mathrm{S}, 77^{\circ} 34^{\prime} \mathrm{W}\right)\end{array}$ & $1,850-1,880 \mathrm{~m}$ & CORBIDI 6909-6911, ZFMK 91746-91748 \\
\hline & Bambamarca & $\begin{array}{l}\text { Calemar } \\
\left(07^{\circ} 32^{\prime} \mathrm{S}, 77^{\circ} 42^{\prime} \mathrm{W}\right)\end{array}$ & $1,440-1,690 \mathrm{~m}$ & CORBIDI 7685-7687, ZFMK 91752-91754 \\
\hline
\end{tabular}


TABLE 2. Four new localities of $P$. delsolari.

\begin{tabular}{|c|c|c|c|c|}
\hline REGIÓN & PROVINCIA & LOCALITY/COORDINATES & ALTITUDE & COLLECTION NUMBERS \\
\hline \multirow[t]{3}{*}{ Cajamarca } & Celendín & Chacanto $\left(06^{\circ} 50^{\prime} \mathrm{S}, 78^{\circ} 01^{\prime} \mathrm{W}\right)$ & $890 \mathrm{~m}$ & CORBIDI 5672, 5673, ZFMK 90871 \\
\hline & & Vijus $\left(07^{\circ} 43^{\prime} \mathrm{S}, 77^{\circ} 39^{\prime} \mathrm{W}\right)$ & $1,260-1,315 \mathrm{~m}$ & CORBIDI 6912, 6913, 7656 ZFMK 91761 \\
\hline & Pataz & & & \\
\hline \multirow[t]{2}{*}{ La Libertad } & & Laguna de Pias $\left(07^{\circ} 53^{\prime} \mathrm{S}, 7^{\circ} 33^{\prime} \mathrm{W}\right)$ & $1,820-1,870 \mathrm{~m}$ & CORBIDI 6914-6916, ZFMK 91759, 91760 \\
\hline & Bambamarca & Calemar $\left(07^{\circ} 30^{\prime} \mathrm{S}, 77^{\circ} 42^{\prime} \mathrm{W}\right)$ & $1,230-1,400 \mathrm{~m}$ & CORBIDI 7654, 7655 ZFMK 91755-91758 \\
\hline
\end{tabular}

AcKNowledgments: We are principally indebted to Pablo J. Venegas for providing access to the collection of the Centro de Ornitología y Biodiversidad (CORBIDI), Lima, Peru, and for his assistance in the planning of the field trips. Wilfredo Nañez Aizcorbe helped with the legal formalities of the collection $\left(\mathrm{N}^{\circ}\right.$ 0020-2009-AG-DGFFS-DGEFFS, 0424-2010-AG-DGFFS-DGEFFS) and export permits (001829-AG-DGFFS, 003983-AG-DGFFS), which were issued to C. Koch by the Dirección General Forestal y de Fauna Silvestre of the Ministerio de Agricultura, Lima, Peru. Antonio García Bravo, Erick Hoyos Granda and Manuel Palacios Panta assisted during the field work and contributed greatly to the success of the field trips. We are indebted to Morris Flecks for the compilation of the distribution map. C. Koch would like to thank the Deutscher Akademischer Austauschdienst (DAAD) and the Alexander Koenig Stiftung for their financial support.

\section{Literature Cited}

Dixon, J.R. and R.B. Huey. 1970. Systematics of the lizards of the gekkonid genus Phyllodactylus of mainland South America. Contributions in Science 192: 1-78.

Koch, C., P.J. Venegas and W. Böhme. 2006. A remarkable discovery: Description of a big-growing new gecko (Squamata: Gekkonidae: Phyllopezus) from northwestern Peru. Salamandra 42 (2/3): 145150.

Venegas, P.J., J.H. Townsend., C. Koch and W. Boehme. 2008. Two new sympatric species of leaf-toed geckos (Gekkonidae: Phyllodactylus) from the Balsas region of the upper Marañon Valley, Peru. Journal of Herpetology 42: 386-396.

RECEIVED: August 2010

LAST REVISED: March 2011

ACCEPTED: March 2011

Published ONLINE: May 2011

EDITORIAL RESPONSIBILITY: Cameron Siler 